\title{
Emergy and energy analysis as an integrative indicator of sustainability: A case study in semi-arid Canadian farmlands
}

\section{Authors: Jianling Fan, Brian G. McConkey, H. Henry Janzen, and Perry R. Miller}

NOTICE: this is the author's version of a work that was accepted for publication in Journal of Cleaner Production. Changes resulting from the publishing process, such as peer review, editing, corrections, structural formatting, and other quality control mechanisms may not be reflected in this document. Changes may have been made to this work since it was submitted for publication. A definitive version was subsequently published in Journal of Cleaner Production, vol. 172, no. 20 (January 2018) DOI\# 10.1016/j.jclepro.2017.10.200

Fan, Jianling, Brian G. McConkey, H. Henry Janzen, and Perry R. Miller. "Emergy and energy analysis as an integrative indicator of sustainability: A case study in semi-arid Canadian farmlands." Journal of Cleaner Production 172, no. 20 (January 2018): 428-437. DOI: 10.1016/ j.jclepro.2017.10.200.

Made available through Montana State University's $\underline{\text { ScholarWorks }}$ scholarworks. montana.edu 


\title{
Emergy and energy analysis as an integrative indicator of sustainability: A case study in semi-arid Canadian farmlands
}

\author{
Jianling Fan ${ }^{\text {a }}$, Brian G. McConkey a, ${ }^{\text {* }}$, H. Henry Janzen ${ }^{\text {b }}$, Perry R. Miller ${ }^{c}$ \\ a Swift Current Research and Development Centre, Agriculture and Agri-Food Canada, 1 Airport Road, Swift Current, SK, S9H 3X2, Canada \\ ${ }^{\mathrm{b}}$ Lethbridge Research and Development Centre, Agriculture and Agri-Food Canada, 54031 Avenue South, Lethbridge, AB, T1J 4B1, Canada \\ ${ }^{\mathrm{c}}$ Land Resources and Environmental Sciences, Montana State University, P.O. Box 173120, Bozeman, MT, 59717-3120, USA
}

\begin{abstract}
A B S T R A C T
Agricultural is essential to feed the human world but it can also degrade the physical world. Therefore, we need widely-accepted metrics to assess how prospective practices influence sustainability. We hypothesized that emergy and energy analyses considered together provide a robust, comprehensive measure of sustainability, and evaluated this hypothesis using findings from two field studies in the semiarid prairie region of Canada: a systems experiment including nine different 3-yr cropping rotation systems and a stubble experiment involving five preceding crop stubbles treatments with three nitrogen $(\mathrm{N})$ addition levels. The grain yield emergy transformities of rotation systems with pulses, ranging from 0.68 to $0.83 \mathrm{E}+05 \mathrm{sej} \mathrm{J}^{-1}$, were $32 \%$ lower $(P<0.05)$ than rotations without pulses. Significantly lower grain transformity of durum wheat grown on pulse stubbles than grown on durum wheat stubble were observed for both the systems and stubble experiments, suggested a higher crop production efficiency conferred by previous pulse crops. The emergy sustainability index (ESI) of Fallow-Durum wheat-Pea (FD-P) rotation (1.94) was $1.3-2.2$ times that of other rotations, while the continuous rotations increased ESI from 1.00-1.11 to $\mathrm{ESI}_{\Delta \mathrm{Q}}$ of $2.00-2.21$ by considering the storage increase $(\Delta Q)$ of the system, i.e. soil organic carbon (SOC). The grain yield/energy input ratio (G/I) and energy output/energy input ratio $(\mathrm{O} / \mathrm{I})$ for F-D-P rotation ( $775 \mathrm{~g} \mathrm{MJ}^{-1}$ and 12.9 , respectively) were significantly $(P<0.05)$ higher than those of all other rotations for its low energy input, which was obtained at the cost of huge SOC decrease. Modified energy use efficiency indices, $\mathrm{G} / \mathrm{I}_{\Delta \mathrm{SOC}}$ and $\mathrm{O} / \mathrm{I}_{\Delta \mathrm{SOC}}$, were proposed in the present study to include the effect of SOC change $(\triangle S O C)$ in energy use efficiency by regarding $\triangle S O C$ as energy input where the system depleted SOC and as energy output where SOC accumulated. The $G / I_{\Delta S O C}$ and $O / I_{\Delta S O C}$ ratios for continuous rotations were significantly $(P<0.05)$ higher than those of other rotations, indicating higher energy use efficiency in continuous rotation systems. Therefore, $\mathrm{ESI}_{\Delta \mathrm{Q}}$ and $\mathrm{O} / \mathrm{I}_{\Delta \mathrm{SOC}}$ are recommended as sustainability indicators in emergy and energy analysis respectively, and we recommend that emergy and energy analysis should be done and considered together to have a more informative assessment of relative sustainability and efficiency of cropping systems.
\end{abstract}

\section{Introduction}

Agricultural ecosystems provide the food, fiber, and fuel needed for human survival and economic development (Hoang and Alauddin, 2011). These lands, however, are often intensively managed, resulting in degradation if improper practices are adopted (Tilman et al., 2002). What is needed, therefore, are comprehensive metrics for assessing whether prospective management systems are sustainable (Zhang et al., 2016); that is, whether they “... aim to make the best use of environmental goods and services while not damaging these assets" (Pretty, 2008).

One prospective metric is emergy analysis, an ecological evaluation that quantifies the solar energy embedded in a food product (Odum, 1988, 1996). This approach integrates resource inputs, energy inputs, and changes in energy stored in the system into a single measure, based on flows of solar energy which drives all ecosystems. By assessing the fundamental currency of agricultural systems - solar energy - emergy analysis may bridge the gap between agronomic and environmental studies of agricultural system 
and offer a ubiquitous estimate potential sustainability (Amaral et al., 2016).

Over the last two decades, emergy analysis has been applied to agricultural systems in various settings (Ferreyra, 2006; Gasparatos, 2011; Ghaley and Porter, 2013; Lefroy and Rydberg, 2003; Park et al., 2016; Zhang et al., 2016) with scales ranging from a single farm (Rótolo et al., 2015) to an entire region (Ferreyra, 2006) or country (Rydberg and Haden, 2006). This approach allows researchers to compare environmental demands of competing farming systems; for example, Rótolo et al. (2015) found that the high intensity hybrid and genetically modified based systems showed lower sustainability and higher demand for environmental support than low intensity system in maize production.

A potentially critical component of such emergy analyses, often overlooked, is soil organic carbon (SOC), widely seen as an indicator of sustainability (Lal, 2004; Tilman et al., 2002). An increase in SOC represents a gain in stored solar energy; a decline represents a loss. Rarely, however, has this parameter been explicitly considered in emergy analysis. Including SOC into emergy analyses could profoundly affect the outcome, but how best to account for SOC change in emergy analysis remains an open question (Lu et al., 2010; Rodrigues et al., 2003).

Researchers have commonly used energy analyses to evaluate agricultural systems, mostly to find ways of reducing external energy inputs (Hoeppner et al., 2007; Khakbazan et al., 2009; Zentner et al., 2011). Such analyses, however, do not consider changes in natural capital or ecosystem function (Brown and Ulgiati, 2004; Franzese et al., 2009). This shortcoming, however, can perhaps be overcome by conducting a concurrent emergy and energy analysis. By conducting an integrated emergy and energy evaluation of rice and vegetable production, Lu et al. (2010) showed that these methods were different but complementary, each revealing a different aspect of the system and answering different questions and concerns.

Our objective is to evaluate the utility of joint emergy and energy analyses to assess the potential sustainability of prospective cropping systems. We address this objective by performing such an analysis using, as a test case, various cropping systems based on durum wheat (Triticum turgidum var durum L.) in the semiarid Canadian prairies. Durum wheat is an important crop on the $\mathrm{Ca}$ nadian prairies, and is grown in diverse systems, varying in fertilizer regime, tillage intensity, and crop rotation (Clarke et al., 2010). These varied practices have pronounced influence on productivity, environmental influence, and soil health (Arcand et al., 2014; Campbell et al., 2002; McConkey et al., 2003; Miller et al., 2002; St. Luce et al., 2015), providing a rich test case for addressing our objective.

\section{Materials and methods}

\subsection{Study sites}

We analyzed durum-based cropping systems using findings from two field experiments, the 'systems experiment' $\left(50^{\circ} 17^{\prime} \mathrm{N}\right.$, $\left.107^{\circ} 34^{\prime} \mathrm{W}\right)$ and the 'stubble experiment' $\left(50^{\circ} 17^{\prime} \mathrm{N}, 107^{\circ} 34^{\prime} \mathrm{W}\right)$, located near Swift Current, Saskatchewan. The climate at these sites, as recorded from a weather station located within $600 \mathrm{~m}$ of the systems experiment, is semi-arid, with 30-year mean annual temperature of $4{ }^{\circ} \mathrm{C}$ and annual precipitation of $351 \mathrm{~mm}$.

The systems experiment, established on Swinton loam (Orthic Brown Chernozem) examined the effects of crop sequences over multiple years including effects of soil organic carbon (SOC) change on durum wheat production. The experiment involved nine cropping systems differing in crop sequence and tillage intensity, which was randomized complete block design with three replicates
Table 1

Cropping systems, cumulative $\mathrm{N}$ application rate, grain yield, grain $\mathrm{N}$ amount, and SOC change $(0-15 \mathrm{~cm})$ in the "Systems experiment" a from 1995 to 2005.

\begin{tabular}{|c|c|c|c|c|c|}
\hline \multirow[t]{2}{*}{ System $^{\mathrm{b}}$} & \multirow[t]{2}{*}{ Tillage $^{c}$} & \multirow{2}{*}{$\frac{\mathrm{N} \text { application }{ }^{\mathrm{d}}}{\left(\mathrm{kg} \mathrm{N} \mathrm{ha}^{-1}\right)}$} & \multirow{2}{*}{$\frac{\text { Grain yield }}{\left(\mathrm{Mg} \mathrm{DM} \mathrm{ha}^{-1}\right)}$} & \multirow{2}{*}{$\frac{\text { Grain N }}{\left(\mathrm{kg} \mathrm{N} \mathrm{ha}^{-1}\right)}$} & \multirow{2}{*}{$\frac{\Delta \mathrm{SOC}}{\left(\mathrm{Mg} \mathrm{C} \mathrm{ha}^{-1}\right)}$} \\
\hline & & & & & \\
\hline F-D-D & MT & 308 & 16.5 & 329 & -1.26 \\
\hline F-D-D & NT & 314 & 16.2 & 317 & -1.13 \\
\hline F-C-D & MT & 327 & 12.5 & 326 & -0.40 \\
\hline F-C-D & NT & 324 & 13.1 & 314 & -0.49 \\
\hline F-D-p & NT & 114 & 17.5 & 478 & -1.63 \\
\hline F-p-D & NT & 224 & 17.7 & 498 & -0.07 \\
\hline p-W-D & NT & 330 & 22.6 & 580 & 0.82 \\
\hline D-O-p & NT & 415 & 18.3 & 544 & 0.16 \\
\hline $\mathrm{D}-\mathrm{O} / \mathrm{p}-\mathrm{p}$ & MT/NT & 235 & 18.0 & 536 & 1.83 \\
\hline$L S D_{0.05}$ & & 33 & 1.8 & 41 & 3.3 \\
\hline
\end{tabular}

a Further details regarding agronomic practices are provided by Shrestha et al. (2013).

b System: F-D-D, Fallow-Durum wheat-Durum wheat; F-C-D, Fallow-CanolaDurum wheat; F-D-p, Fallow-Durum wheat-pulse; F-p-D, Fallow-pulse-Durum wheat; p-W-D, pulse-winter Wheat-Durum wheat; D-O-p, Durum wheat-Oilseedpulse; D-O/p-p, Durum wheat-Oilseed-pulse in 1995-1998, and Durum wheatchickpea-pulse in 1999-2005 (Oilseed was flax in 1995-1997, sunflower in 1998-2000 and canola in 2001-2005; pulse was lentil in 1995, chickpea in 1996-1997 and pea in 1998-2005). Each rotation system had three phases and all phases were present every year.

c Tillage: MT, minimum tillage; NT, no tillage; W-O/p-p was MT in 1995-2000 and NT in 2001-2005.

d Mean rate of $\mathrm{N}$ application per crop year was $5 \mathrm{~kg} \mathrm{~N}^{-1}$ for pulses (from the $\mathrm{P}$ fertilizer), $27 \mathrm{~kg} \mathrm{~N} \mathrm{ha}^{-1}$ for cereal grown on fallow, $30 \mathrm{~kg} \mathrm{~N}^{-1}$ for oilseed grown on fallow, and 50 and $57 \mathrm{~kg} \mathrm{~N} \mathrm{ha}^{-1}$ for cereal and oilseed, respectively, grown on stubble. Monoammonium phosphate (12-51-0) was applied to all crops at $25 \mathrm{~kg}$ $\mathrm{P}_{2} \mathrm{O}_{5}$ ha $^{-1}$

(Table 1). Soil samples to a depth of $15 \mathrm{~cm}$ were collected in 1995 and 2006, and analyzed for SOC as described by Shrestha et al. (2013). Soil organic matter (SOM) content was calculated as SOC multiplied by 1.72 . Grain yield was measured annually from a representative portion of each plot, and its nitrogen $(\mathrm{N})$ concentration determined by near-infrared analysis or, in the case of oilseeds and pulses, estimated from the scientific literature (Janzen et al., 2003).

The stubble experiment, established on a Haverhill loam (Orthic Brown Chernozem), examined the effect of preceding crop and $\mathrm{N}$ fertilizer on durum wheat. During the test year, durum wheat was uniformly seeded into plots which, in the preceding year, had been planted to durum wheat, mustard (Brassica juncea L.), lentil (Lens culinaris Medik.), chickpea (Cicer arietinum L.), or pea (Pisum sativum L.) under no-till conditions using recommended fertilizer and pest control practices similar to those in the systems experiment. The durum wheat, in the test year, was grown under three $\mathrm{N}$ fertilizer rates $\left(34,50\right.$, and $\left.78 \mathrm{~kg} \mathrm{~N} \mathrm{ha}^{-1}\right)$, corresponding to general recommendations for dry, normal, and wet growing conditions, respectively. Monoammonium phosphate (12-51-0) was applied to all treatments at $22.4 \mathrm{~kg} \mathrm{P}_{2} \mathrm{O}_{5} \mathrm{ha}^{-1}$. The experiment had four durum wheat test years, 1999-2002, with each stubble-test year sequence on a separate area within the overall experiment. Treatments were replicated four times in a split-plot randomized complete block design, with preceding crop as main plot and fertilizer rate as the split plot.

\subsection{Estimation of SOC change}

For the systems experiment, changes in SOC were estimated from the beginning in 2002 to ensure that crop rotations were wellestablished and under consistent cropping. Previous analysis showed a linear relationship between SOC change and residue C inputs (Shrestha et al., 2013), indicating that the effect of crop rotation on SOC was mainly through their effect on $C$ inputs. The 
rate of SOC change from 2002 to 2005 was estimated from changes measured from 1995 to 2005 (Table 2), based on a strong correlation between C inputs from 2002 to 2005 and those in 1995-2001 $(P<0.01$; Fig. A.1), indicating that the relative rates and magnitudes of crop residue $C$ inputs on SOC change from 2002 to 2005 should be similar as from 1995 to 2001. However, no attempt was made to measure changes in SOC in the stubble experiment due to the short duration of the two-year crop sequence.

\subsection{Emergy analysis}

In accordance with method of Odum (1996), we first defined the spatial and temporal boundaries of rotation systems; namely, the relevant plot areas on a one year time step (Fig. A.2). Solar emergy flows were then calculated for each treatment in the systems and stubble experiment, using factors extracted from the literature (Table A.1-4). All input and output emergy flows were summed by category and a net value was calculated using a planetary baseline of 12.0E $+24 \mathrm{sej} / \mathrm{year}$ (Brown et al., 2016). Briefly, emergy inputs for crop production system can be classified into four types: (1) local renewable resources $(R)$, such as sunlight, rain, wind, earth circle, and atmospheric nitrogen deposition; (2) local nonrenewable resources $(N)$, which we considered as soil degradation (Lefroy and Rydberg, 2003; Zhang et al., 2007), i.e. net loss of SOM; (3) purchased nonrenewable resources $\left(F_{N}\right)$, such as mineral fertilizers, chemicals (herbicides and inoculant), machinery and diesel use; (4) purchased renewable resources $\left(F_{R}\right)$, which we considered as labor and seeds (Ma et al., 2015; Zhai et al., 2017; Zhang et al., 2016). The net loss of SOC during the study period was counted as local nonrenewable resources $(N)$, while the net increase in SOC was counted as a co-product with the output of grain yield.

\subsection{Energy analysis}

The energy performance was determined using methods described by Zentner et al. (2011). The physical quantities of production inputs (fertilizers, herbicides, inoculant, diesel, machinery, labor and seeds) and crop yield were converted to energy values $\left(\mathrm{MJ} \mathrm{ha}^{-1}\right.$ ) using appropriate energy coefficients (Table A.5). Energy in the crop residue was not included as energy output since it was returned to the land after harvest. Grain production per unit of energy input $\left(\mathrm{G} / \mathrm{I}, \mathrm{g} \mathrm{MJ}^{-1}\right)$ and energy output to energy input ratio $\left(\mathrm{O} / \mathrm{I}, \mathrm{MJ} \mathrm{MJ}^{-1}\right)$ were calculated to evaluate the energy use efficiency.
In the past, energy analyses have rarely considered changes in energy storage resulting from gains or losses of SOC (Khakbazan et al., 2009; Zentner et al., 2011). However, such changes are an important component of any energy analysis. Therefore, we propose two additional parameters, $\mathrm{G} / \mathrm{I}_{\Delta \mathrm{SOC}}\left(\mathrm{g} \mathrm{MJ}^{-1}\right)$ and $\mathrm{O} / \mathrm{I}_{\Delta \mathrm{SOC}}(\mathrm{MJ}$ $\mathrm{MJ}^{-1}$ ), by considering SOC change as an energy input where SOC decrease but as an energy output where SOC increase:

$G / I_{\Delta S O C}=\frac{Y}{\left(E_{i n}+\left|E_{\Delta S O C}\right|\right)}, \quad \Delta S O C<0$

$O / I_{\Delta S O C}= \begin{cases}\frac{E_{\text {out }}}{\left(E_{\text {in }}+\left|E_{\Delta S O C}\right|\right)}, & \Delta S O C<0 \\ \frac{\left(E_{\text {out }}+E_{\Delta S O C}\right)}{E_{\text {in }}}, & \Delta S O C>0\end{cases}$

where $Y$ is the grain yield (g); $E_{\text {in }}$ represents energy input (MJ); $E_{\text {out }}$ represents energy output $(\mathrm{MJ}) ; E_{\triangle S O C}$ is the energy flow of SOC change (MJ).

\subsection{Data analysis}

All data were analyzed with mixed models, where tillage, previous crop or fallow, and crop species were treated as fixed effects in the systems experiment and fertilizer $\mathrm{N}$ level and crop stubble were treated as fixed effects in the stubble experiment. Year and replicate were treated as random effects in both experiments. Least significant difference (LSD) at 5\% level was used to test difference between treatments. For comparing groups of treatments (e.g. tillage systems), single degree of freedom contrasts were used with $5 \%$ level to determine significant differences. All statistical analysis were performed using R software (R Core Team, 2015).

\section{Results}

\subsection{Agronomic performance}

\subsubsection{Systems experiment}

All systems with fallow had apparent loss of SOC (Table 1). For the systems without pulse crops, $\mathrm{N}$ applied in fertilizer approximately equaled $\mathrm{N}$ removed in grain. In 2002-2005, yield of durum wheat on cereal stubble was lower than yield of durum wheat on fallow (Table 2). The productivity of durum wheat was highest on

Table 2

Average annual grain yield ( $\mathrm{kg} \mathrm{FW} \mathrm{ha}^{-1}$ ) of different crops in systems experiment from 2002 to 2005.

\begin{tabular}{|c|c|c|c|c|c|c|c|c|}
\hline \multicolumn{3}{|c|}{ Durum wheat } & \multicolumn{3}{|l|}{ Canola } & \multicolumn{3}{|l|}{ Pulse } \\
\hline Rotation $^{a}$ & Tillage $^{b}$ & Yield & Rotation & Tillage & Yield & Rotation & Tillage & Yield \\
\hline \multicolumn{9}{|c|}{ kg FW ha ${ }^{-1}$} \\
\hline F-(D)-D & MT & 3056 & F-(C)-D & MT & 1664 & F-D-(P) & NT & 2939 \\
\hline F-D-(D) & MT & 2394 & $\mathrm{~F}-(\mathrm{C})-\mathrm{D}$ & NT & 1816 & $F-(P)-D$ & NT & 3185 \\
\hline F-(D)-D & NT & 2887 & D-(C)-P & NT & 1532 & $\mathrm{D}-\mathrm{C}-(\mathrm{P})$ & NT & 2740 \\
\hline F-D-(D) & NT & 2341 & & & & (P)-W-D & NT & 2835 \\
\hline F-C-(D) & MT & 2483 & & & & D-cP-(P) & NT & 2527 \\
\hline F-C-(D) & NT & 2670 & & & & $\mathrm{D}-(\mathrm{cP})-\mathrm{P}$ & NT & 1168 \\
\hline F-(D)-P & NT & 3162 & & & & & & \\
\hline F-P-(D) & NT & 2927 & & & & & & \\
\hline (D)-C-P & NT & 2656 & & & & & & \\
\hline P-(W)-D & NT & 3143 & & & & & & \\
\hline P-W-(D) & NT & 2233 & & & & & & \\
\hline (D)-cP-P & NT & 2699 & & & & & & \\
\hline$L S D$ & & 426 & & & 419 & & & 397 \\
\hline
\end{tabular}

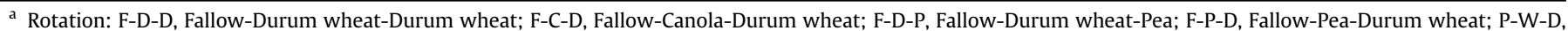
Pea-winter Wheat-Durum wheat; D-C-P, Durum wheat-Canola-Pea; D-cP-P, Durum wheat-chickpea-Pea.

b Tillage: MT, minimum tillage; NT, no tillage. 
fallow after pea (F-(D)-P; $3.16 \mathrm{Mg} \mathrm{FW} \mathrm{ha}^{-1}$ ), which was higher than that of durum wheat on cereal or canola stubbles. Canola yield did not differ significantly between rotations. Pea yield was higher after fallow than after canola or chickpea. There were no significant differences between NT and MT for crop yields.

\subsubsection{Stubble experiment}

Overall, durum wheat yield was higher with 50 than with $34 \mathrm{~kg} \mathrm{~N} \mathrm{ha}^{-1}$ application, but a further increase in $\mathrm{N}$ rate elicited no additional yield response (Fig. 1). Durum wheat yield was higher after pulses than after cereals. Durum grain protein content increased with increasing levels of $\mathrm{N}$ fertilizer added (Fig. 1), and was higher after pulses than after mustard or wheat.

\subsection{Emergy analysis}

\subsubsection{Total emergy input and its composition}

For the systems experiment, all rotation systems were highly dependent on purchased non-renewable resources $F_{N}$, which accounted for $34-61 \%$ of total emergy input (Table 3), followed by local renewable resources $R(28-39 \%)$, purchased renewable resources $F_{R}(5-12 \%)$ and local non-renewable resources $N(0-24 \%)$, respectively. Chemical fertilizers were the largest emergy input in $F_{N}$, accounting for $60-81 \%$ of $F_{N}$ emergy input (Table 3 ). Only three
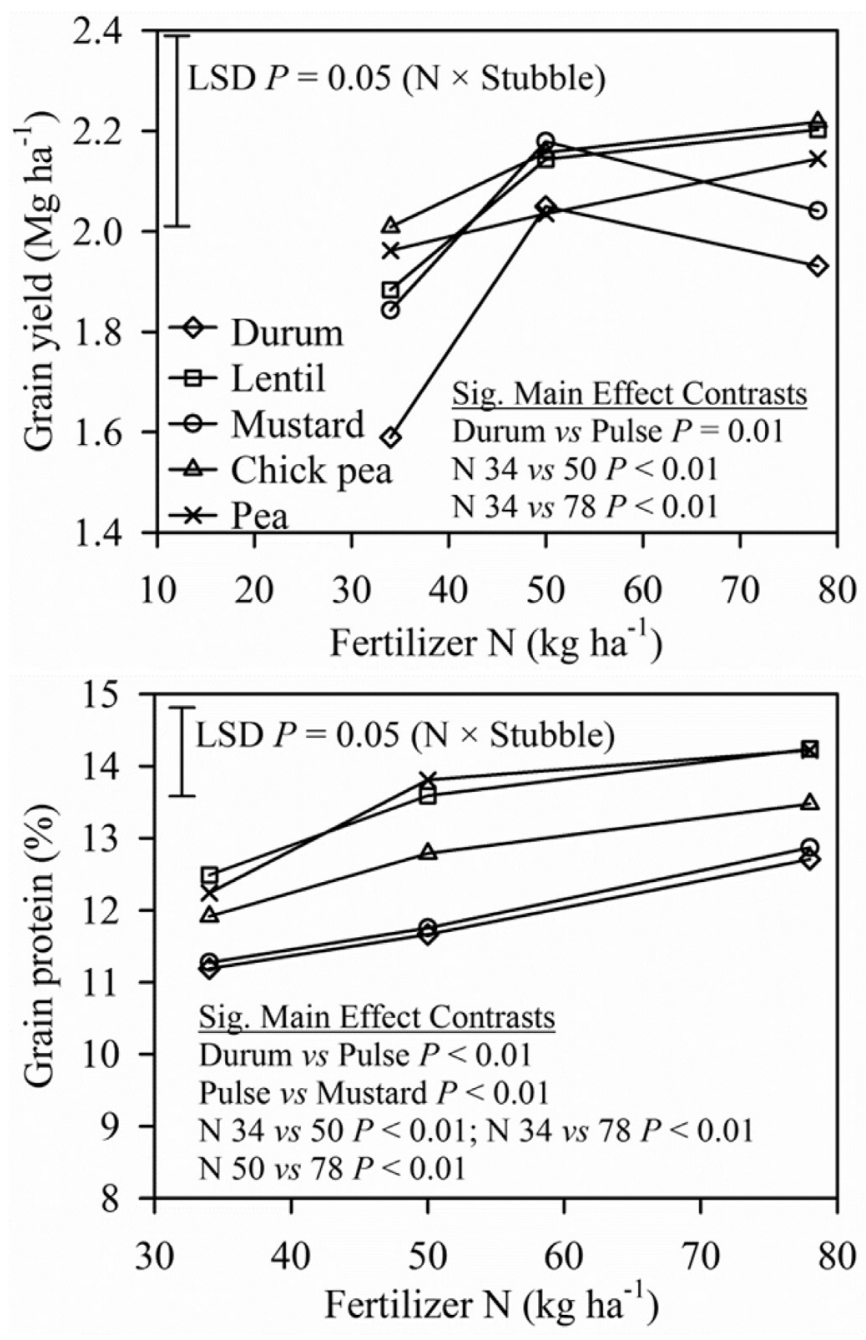

Fig. 1. Effects of fertilizer $\mathrm{N}$ level and crop stubbles on durum wheat grain yield and protein content in stubble experiment from 1999 to 2002. continuous rotation systems (i.e. P-W-D, D-C-P, and D-cP-P) did not consume SOC (i.e. no requirement from $N$ ) in nine rotation systems, while six other systems had emergy input from $N$ ranging from $1 \%$ (F-P-D) to 24\% (F-D-P) of total emergy input. Rotation F-P-D had the lowest emergy density, 70-91\% that of other rotation systems, mainly because of lower emergy input from $\mathrm{N}$ fertilizer. F-D-P rotation received less $\mathrm{N}$ fertilizer but caused much greater loss of SOC than all other treatments, resulting in lower emergy density.

The purchased non-renewable resources $\left(F_{N}\right)$ and total emergy input $(U)$ under NT were lower than under MT, primarily due to higher emergy input as diesel fuel and machinery $\left(F_{N}\right.$-DM) under MT. Emergy input from $\mathrm{N}$ fertilizer $\left(F_{N^{-}} \mathrm{N}\right)$ was similar for NT and MT (Table 3).

\subsubsection{Transformity}

The transformity of products can be used to measure the relative efficiency of the system's production process; the higher the transformity, the lower the long-term economic and environmental efficiency of production (Lu et al., 2010; Odum, 1996). The grain yield transformities of rotation systems with pulses (F-D-P, F-P-D, P-W-D, D-C-P and D-CP-P) averaged 32\% lower than rotations without pulses (Table 3), indicating that pulses improved system production efficiency.

The three continuous cropping systems showed an increase in SOC, as reflected in the transformity values (Table 3). Significant differences of the transformity of SOC accumulation were obtained among three continuous rotation systems, where D-cP-P rotation showed 4 times and 11 times higher efficiency than P-W-D and DC-P systems in improving SOC.

\subsubsection{Emergy evaluation indices}

Emergy yield ratio (EYR) is the fundamental emergy indicator of yield compared to external inputs, which is a measure of the ability of systems to exploit local resources (Brown and Ulgiati, 1997; Odum, 1996). The EYR of F-D-P was higher than that of other rotation systems, and fallow-including rotations generally showed higher EYR than continuous cropping (Table 3), reflecting the subsidies from SOC declines.

Environmental loading ratio (ELR) is a measure of the potential anthropogenic pressure on local ecosystems (Lu et al., 2010). The higher the ELR, the greater the environmental pressure (Odum, 1996). The ELR of F-P-D was lower than that of other rotation systems (Table 3), mainly due to its low dependence on $F_{N}$ (especially chemical fertilizers) and $N$ (SOC decrease). Although the continuous rotation systems (i.e. P-D-D, D-C-P, and D-cP-P) did not consume SOC $(N=0)$, they relied on more $F_{N}$, resulting in higher ELR values.

Emergy sustainability index (ESI), the most widely used emergy indicator of system sustainability, reflects the ratio of yield versus environmental loading (Brown and Ulgiati, 1997). The ESI of F-D-P (1.94) was 1.3-2.2 times that of other rotation systems, as a result of its high EYR and low ELR values (Table 3).

The emergy benefit ratio (EBR) takes into account any increases in natural capital that may occur as a result of production (Lu et al., 2009). Because of increases in SOC, the continuous rotation systems (i.e. P-D-D, D-C-P, and D-cP-P) showed higher EBR than other systems (Table 3). The EBR of F-D-P was lower than those of the continuous rotation systems but higher than those of other rotations.

ESI after considering the change of storage $\left(\mathrm{ESI}_{\Delta Q}\right)$ is an indicator of system sustainability considering both the change in internal ecological capital and the emergy yield (Lu et al., 2009). The continuous rotation systems increased ESI from 1.00 to 1.11 to $\mathrm{ESI}_{\Delta \mathrm{Q}}$ of $2.00-2.21$ by considering the storage increase $(\Delta Q)$, while other systems had the same $\mathrm{ESI}_{\Delta Q}$ as ESI values for no system storage 
Table 3

Emergy flows, indices and transformities of different crop rotations in systems experiment from 2002 to 2005.

\begin{tabular}{|c|c|c|c|c|c|c|c|c|c|c|c|c|c|c|c|c|c|c|}
\hline \multirow[t]{2}{*}{ Rotation $^{\text {a }}$} & \multirow[t]{2}{*}{ Tillage } & \multicolumn{10}{|c|}{ Emergy flows ${ }^{\mathrm{b}}\left(\mathrm{E}+14\right.$ sej ha $\left.{ }^{-1} \mathrm{yr}^{-1}\right)$} & \multicolumn{5}{|c|}{ Emergy indices $^{c}$} & \multicolumn{2}{|c|}{ Transformity ${ }^{\mathrm{d}}\left(\right.$ sej J $\left.^{-1}\right)$} \\
\hline & & $R$ & $N$ & $F_{R}$ & $F_{N}-\mathrm{P}$ & $F_{N}-\mathrm{N}$ & $F_{N^{-}} \mathrm{C}$ & $F_{N}$-DM & $F_{N}$ & $U$ & $\Delta Q$ & EYR & ELR & ESI & EBR & $\mathrm{ESI}_{\Delta Q}$ & Grain $(E+05)$ & $\mathrm{SOC}(\mathrm{E}+06)$ \\
\hline F-D-D & MT & 8.10 & 4.33 & 1.67 & 2.04 & 7.83 & 1.40 & 3.91 & 15.2 & 29.3 & 0 & 1.75 & 2.00 & 0.89 & 1.75 & 0.89 & 1.21 & \\
\hline F-D-D & NT & 8.10 & 3.66 & 1.40 & 2.04 & 8.12 & 1.40 & 1.00 & 12.6 & 25.7 & 0 & 1.85 & 1.72 & 1.10 & 1.85 & 1.10 & 1.11 & - \\
\hline F-C-D & MT & 8.10 & 1.33 & 3.05 & 2.04 & 7.88 & 1.36 & 3.92 & 15.2 & 27.7 & 0 & 1.53 & 1.49 & 1.06 & 1.53 & 1.06 & 1.20 & - \\
\hline F-C-D & NT & 8.10 & 1.66 & 2.78 & 2.04 & 7.99 & 1.36 & 1.00 & 12.4 & 24.9 & 0 & 1.66 & 1.30 & 1.34 & 1.66 & 1.34 & 1.01 & - \\
\hline F-D-P & NT & 8.10 & 5.33 & 1.53 & 2.04 & 2.48 & 2.02 & 1.01 & 7.5 & 22.5 & 0 & 2.52 & 1.35 & 1.94 & 2.52 & 1.94 & 0.81 & - \\
\hline F-P-D & NT & 8.10 & 0.33 & 1.53 & 2.04 & 5.51 & 2.02 & 1.01 & 10.6 & 20.5 & 0 & 1.70 & 1.14 & 1.50 & 1.70 & 1.50 & 0.75 & - \\
\hline P-W-D & NT & 8.10 & 0 & 2.18 & 3.06 & 9.48 & 2.08 & 1.39 & 16.0 & 26.3 & 26.3 & 1.46 & 1.57 & 1.00 & 2.92 & 2.00 & 0.68 & 0.91 \\
\hline D-C-P & NT & 8.10 & 0 & 3.56 & 3.06 & 10.41 & 2.04 & 1.39 & 16.9 & 28.6 & 28.6 & 1.40 & 1.46 & 1.01 & 2.81 & 2.02 & 0.79 & 4.03 \\
\hline D-cP-P & NT & 8.10 & 0 & 2.49 & 3.06 & 5.79 & 3.95 & 1.43 & 14.2 & 24.8 & 24.8 & 1.48 & 1.35 & 1.11 & 2.97 & 2.21 & 0.83 & 0.38 \\
\hline$L S D$ & & - & - & - & - & 2.18 & - & - & 2.2 & 2.2 & 3.1 & 0.13 & 0.20 & 0.27 & 0.15 & 0.39 & 0.19 & 0.32 \\
\hline
\end{tabular}

a Abbreviations for rotation, tillage are same as in Table 2.

b Emergy flows: $R$, local renewable resources input; $N$, local non-renewable resources input; $F_{R}$, purchased renewable input; $F_{N}$, purchased non-renewable input; $F_{N}$-P,

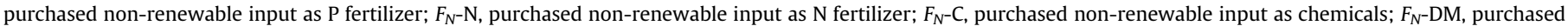
non-renewable input as diesel and machinery; $U$, total emergy input (empower density), which equal to total emergy output $Y$; $\Delta Q$, increase of system storage.

${ }^{c}$ Emergy indices: $\mathrm{EYR}=Y /\left(F_{N}+F_{R}\right)$, emergy yield ratio; $\mathrm{ELR}=\left(F_{N}+N\right) /\left(F_{R}+R\right)$, environmental loading ratio; $\mathrm{ESI}=\mathrm{EYR} / \mathrm{ELR}$, emergy sustainability index; EBR $=(Y+\Delta Q) /$ $\left(F_{N}+F_{R}\right)$, emergy benefit ratio; $\mathrm{ESI}_{\Delta \mathrm{Q}}=\mathrm{EBR} / \mathrm{ELR}$, ESI after considering the change of storage.

d Calculated product transformity in the present study.

\section{change (Table 3 ).}

For the stubble experiment, the total emergy inputs of different treatments were the same as those for the systems experiment (Table 3) except for that due to fertilizer $\mathrm{N}$ level $\left(F_{N}-\mathrm{N}\right)$, which accounted for $41 \%$ (low $\mathrm{N}$ level) to $61 \%$ (high $\mathrm{N}$ level) of total emergy input (Table 4). Emergy indices were also affected by $\mathrm{N}$ levels with notably lower EYR, ESI, EBR, and $\mathrm{ESI}_{\Delta Q}$ but higher ELR with increasing $\mathrm{N}$ level (Table 4), indicating higher environmental pressure and lower system sustainability with higher fertilizer $\mathrm{N}$ application. There were no significant effects of prior crop under the same $\mathrm{N}$ level since all received the same emergy inputs.

\subsubsection{Emergy analysis for durum wheat}

Durum is a common crop across systems and experiments and so its performance provides useful comparison between systems and input levels. For the systems experiment, total emergy input $(U)$ and grain transformity of durum wheat grown on durum wheat stubble were higher than those of durum wheat grown on canola or pea stubbles (Fig. 2), indicating higher efficiency of durum wheat production in rotations with higher crop diversification. Furthermore, the $\mathrm{ESI}_{\Delta Q}$ of durum wheat was higher under NT than under MT (Fig. 2), indicating higher system sustainability under NT. Durum wheat transformity value trends indicated that adoption of NT and elimination of fallow increased production efficiency (Fig. 2).

Significant effects of crop stubble and N level on durum wheat yield transformity were observed in stubble experiment (Fig. 3). The transformity of durum wheat production was linearly increased with the increase of fertilizer $\mathrm{N}$ level $\left(\mathrm{R}^{2}=0.610\right.$, $P<0.001, n=15$ ), indicating lower grain production efficiency with high $\mathrm{N}$ addition although medium and high $\mathrm{N}$ levels significantly increased durum wheat yield compared to low N level (Fig. 1). Furthermore, the transformity of durum wheat production grown on durum wheat stubble was higher than that of durum grown on pulse and mustard stubbles, showing that previous pulse crops or mustard promoted durum wheat production efficiency (Fig. 3).

\subsection{Energy analysis}

\subsubsection{Energy flows}

For the systems experiment, total energy input of rotation systems was significantly related to energy input from $\mathrm{N}$ fertilizer $\left(R^{2}=0.70, P<0.01\right)$, which accounted for $24-55 \%$ of total energy input (Table 5). Energy output of grain from continuous rotation systems (P-W-D, D-C-P, and D-cP-P), was about 35\% higher than of grain from fallow-including rotations. Moreover, F-D-P and F-P-D rotations showed higher (16\%) grain energy output than F-D-D and F-C-D rotations, indicating that pulse-including rotations gained higher grain energy than rotations without pulses. Total energy input for rotation systems under NT was lower than under MT but no significant influence of tillage on grain energy was obtained (Table 5).

Total energy input ranged from $4499 \mathrm{MJ} \mathrm{ha}^{-1} \mathrm{yr}^{-1}$ for low $\mathrm{N}$ level treatments to $7508 \mathrm{MJ} \mathrm{ha}^{-1} \mathrm{yr}^{-1}$ for high $\mathrm{N}$ level treatments in the stubble experiment, largely reflecting differences in $\mathrm{N}$ fertilizer input, which accounted for $52-71 \%$ of total energy input (Table 4 ).

\subsubsection{Energy use efficiency}

Grain yield/energy input ratio (G/I) and energy output/energy input ratio $(\mathrm{O} / \mathrm{I})$ for $\mathrm{F}-\mathrm{D}-\mathrm{P}$ rotation was higher than that of all other rotation systems (Table 5), mainly due to its low energy input compared to other rotations. However, high G/I and O/I ratios of FD-P rotation were obtained at the cost of huge SOC decrease $\left(-5668 \mathrm{MJ} \mathrm{ha}^{-1} \mathrm{yr}^{-1}\right)$. Modified energy use efficiency, G/I $/ \Delta$ SOc and $\mathrm{O} / \mathrm{I}_{\Delta \mathrm{SOC}}$ ratios, were calculated to include the effect of SOC change in energy use efficiency. The highest $\mathrm{G} / \mathrm{I}_{\Delta \mathrm{SOC}}$ and $\mathrm{O} / \mathrm{I}_{\Delta \mathrm{SOC}}$ ratios were obtained for P-W-D rotation (551 $\mathrm{g} \mathrm{MJ}^{-1}$ and $9.8 \mathrm{MJ} \mathrm{MJ}^{-1}$, respectively), followed by D-C-P, D-CP-P and F-P-D rotations

Table 4

Emergy flows, indices, grain transformities, energy flows, and energy use efficiency of durum wheat under different fertilizer $\mathrm{N}$ level from 1999 to 2002.

\begin{tabular}{|c|c|c|c|c|c|c|c|c|c|}
\hline \multirow[t]{2}{*}{$\mathrm{N}$ level } & \multicolumn{2}{|c|}{ Emergy flow (E+14 sej ha $\left.{ }^{-1} \mathrm{yr}^{-1}\right)$} & \multicolumn{5}{|c|}{ Emergy indices } & \multicolumn{2}{|c|}{ Energy flow (MJ ha $\left.{ }^{-1} \mathrm{yr}^{-1}\right)$} \\
\hline & $\overline{F_{N^{-}} \mathrm{N}}$ & Other emergy input & EYR & ELR & ESI & EBR & $\mathrm{ESI}_{\Delta Q}$ & $\mathrm{~N}$ fertilizer & Other energy \\
\hline Low & 10.44 & 15.33 & 1.43 & 1.67 & 0.87 & 2.86 & 1.75 & 2326 & 2173 \\
\hline Medium & 15.35 & 15.33 & 1.34 & 2.18 & 0.62 & 2.68 & 1.25 & 3420 & 2173 \\
\hline High & 23.95 & 15.33 & 1.25 & 3.07 & 0.41 & 2.49 & 0.82 & 5335 & 2173 \\
\hline
\end{tabular}



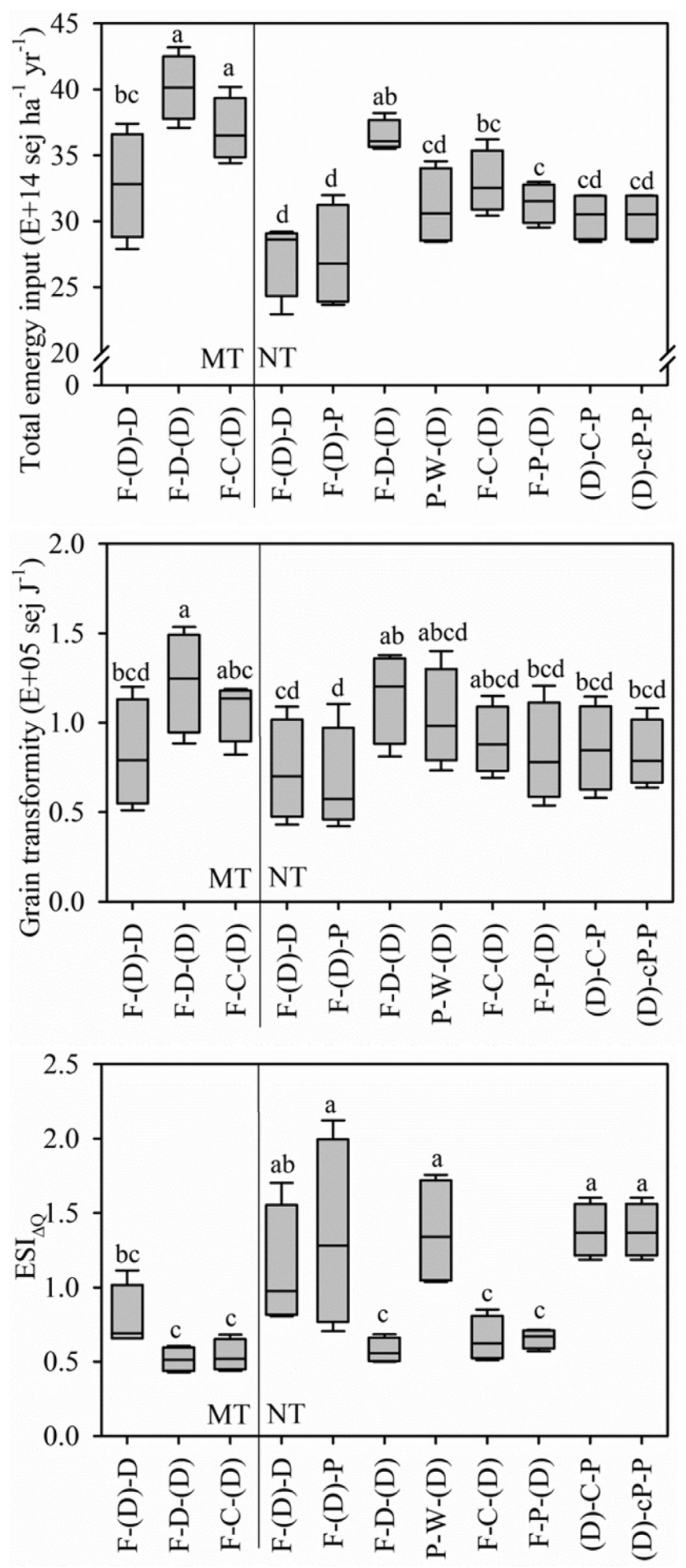

Fig. 2. Total emergy input, grain transformity, and $\mathrm{ESI}_{\Delta \mathrm{Q}}$ of durum wheat in different rotation systems from 2002 to 2005. See Table 2 for abbreviations of rotation systems.

(466-522 $\mathrm{g} \mathrm{MJ}^{-1}$ for $\mathrm{G} / \mathrm{I}_{\Delta \mathrm{SOC}}$ and 8.7-9.5 $\mathrm{MJ} \mathrm{MJ}^{-1}$ for $\mathrm{O} / \mathrm{I}_{\Delta \mathrm{SOC}}$ ), which were higher than those of other rotations. This result further suggested higher energy use efficiency in pulse including rotations.

The $\mathrm{G} / \mathrm{I}_{\Delta \mathrm{SOC}}$ of pea under NT $\left(701 \mathrm{~g} \mathrm{MJ}^{-1}\right)$ was $2.4,2.2$, and 2.6 times that of durum wheat, canola and chickpea, respectively, while $\mathrm{O} / \mathrm{I}_{\Delta \mathrm{SOC}}$ of pea under NT (12.3) was $2.4,1.5$, and 1.9 times that of
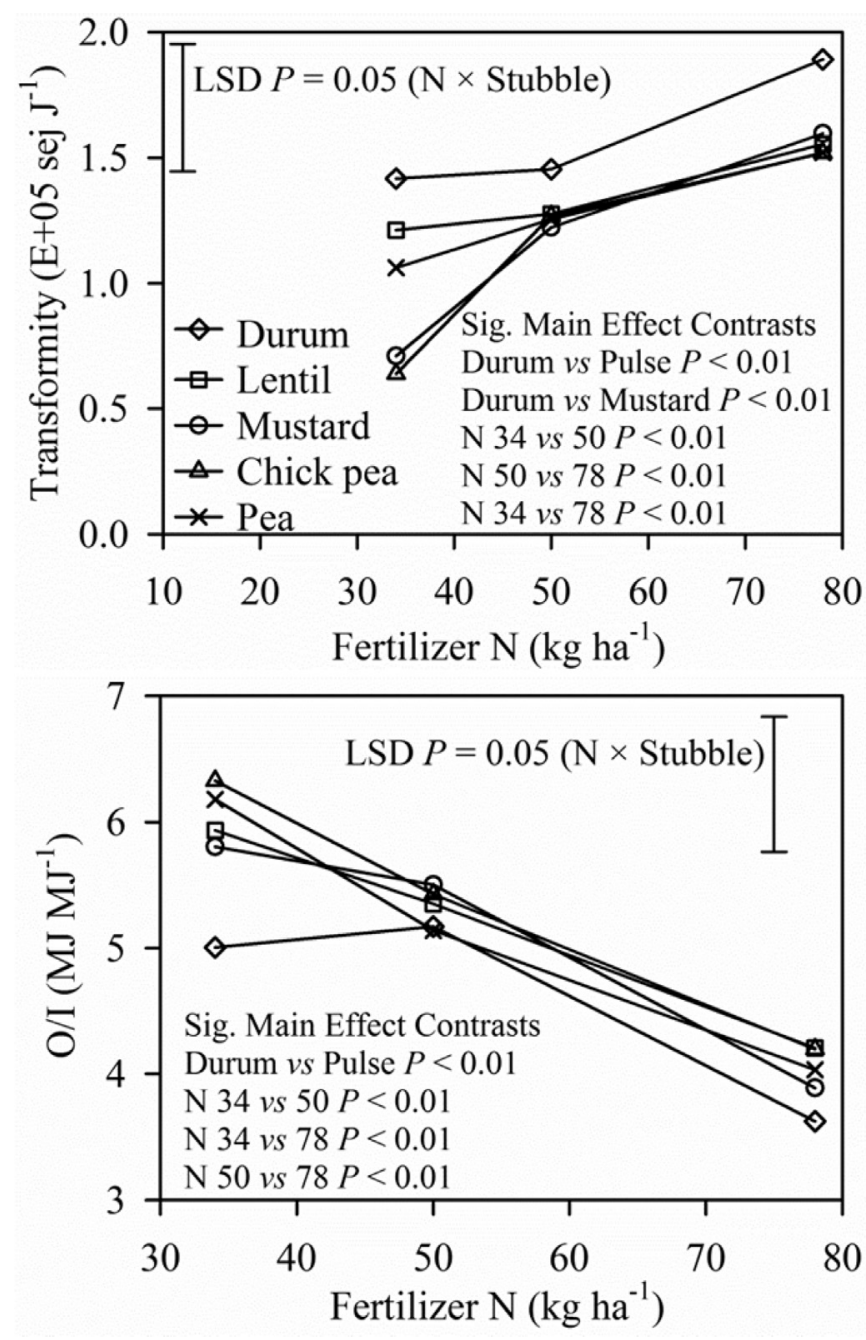

Fig. 3. Grain transformity and $\mathrm{O} / \mathrm{I}$ of durum wheat under different $\mathrm{N}$ level in stubble experiment from 1999 to 2002.

durum wheat, canola and chickpea, respectively (data not shown). These results showed higher energy use efficiency of pea than of other crops. However, energy use efficiencies of chickpea were much lower than of pea, primarily due to its low grain yield.

\subsubsection{Energy analysis for durum wheat grown on different stubbles}

Total energy input for durum wheat grown after fallow or pea was lower than that of durum after durum wheat, but no differences in grain energy were observed for durum wheat grown after various other crops (Fig. 4). Energy use efficiency for durum wheat grown on pea stubbles $\left(\mathrm{O} / \mathrm{I}_{\Delta \mathrm{SOC}}=7.0-8.3\right)$ was markedly higher than for durum wheat grown on canola and durum wheat stubbles, and $\mathrm{O} / \mathrm{I}_{\Delta \mathrm{SOC}}$ for durum wheat grown on canola stubble (5.1) was also higher than for durum wheat grown on durum wheat stubble (3.4) (Fig. 4). These results further suggested higher energy use efficiency of durum wheat production induced by previous canola and pulse crops.

Energy output of durum wheat grown on durum wheat stubble under low fertilizer $\mathrm{N}$ level was $17-22 \%$ lower than that of durum wheat grown under medium and high $\mathrm{N}$ level treatments, reflecting yield differences (Fig. 1). But energy output of durum wheat grown on mustard and pulse stubble under low fertilizer $\mathrm{N}$ level were $11-15 \%$ and $3-15 \%$ lower than those of durum wheat under medium and high $\mathrm{N}$ level treatments. Furthermore, grain energy 
Table 5

Energy flows and energy use efficiency of different crop rotations in systems experiment from 2002 to 2005.

\begin{tabular}{|c|c|c|c|c|c|c|c|c|c|c|c|c|c|}
\hline \multirow[t]{3}{*}{ Rotation $^{\text {a }}$} & \multirow[t]{3}{*}{ Tillage } & \multicolumn{8}{|c|}{ Energy flow (MJ ha ${ }^{-1} \mathrm{yr}^{-1}$ ) } & \multicolumn{4}{|c|}{ Energy use efficiency } \\
\hline & & \multirow{2}{*}{$\begin{array}{l}\text { Phosphorus } \\
\text { fertilizer }\end{array}$} & \multirow{2}{*}{$\begin{array}{l}\text { Nitrogen } \\
\text { fertilizer }\end{array}$} & \multirow[t]{2}{*}{ Chemicals } & \multirow{2}{*}{$\begin{array}{l}\text { Diesel \& } \\
\text { machinery }\end{array}$} & \multirow{2}{*}{$\begin{array}{l}\text { Labor \& } \\
\text { seeds }\end{array}$} & \multirow[t]{2}{*}{ Total input } & \multirow{2}{*}{$\begin{array}{l}\text { Grain } \\
\text { energy }\end{array}$} & \multirow[t]{2}{*}{$\Delta \mathrm{SOC}$} & $\mathrm{G} / \mathrm{I}$ & $\mathrm{G} / \mathrm{I}_{\Delta \mathrm{SOC}}$ & $\mathrm{O} / \mathrm{I}$ & $\mathrm{O} / \mathrm{I}_{\Delta \mathrm{SOC}}$ \\
\hline & & & & & & & & & & \multicolumn{2}{|c|}{$\left(\mathrm{g} \mathrm{MJ}^{-1}\right)$} & \multicolumn{2}{|c|}{$\left(\mathrm{MJ} \mathrm{MJ}^{-1}\right)$} \\
\hline F-D-D & MT & 205 & 1744 & 379 & 1167 & 576 & 4072 & 25739 & -4606 & 393 & 182 & 6.4 & 3.0 \\
\hline F-D-D & NT & 205 & 1809 & 379 & 578 & 568 & 3540 & 24685 & -3897 & 432 & 204 & 7.1 & 3.3 \\
\hline F-C-D & MT & 205 & 1755 & 368 & 1186 & 319 & 3834 & 24367 & -1417 & 317 & 230 & 6.4 & 4.7 \\
\hline F-C-D & NT & 205 & 1781 & 368 & 583 & 311 & 3249 & 26406 & -1771 & 408 & 261 & 8.3 & 5.3 \\
\hline F-D-P & NT & 205 & 553 & 545 & 588 & 449 & 2340 & 29345 & -5668 & 775 & 221 & 12.9 & 3.7 \\
\hline F-P-D & NT & 205 & 1228 & 545 & 588 & 449 & 3016 & 29439 & -354 & 583 & 522 & 9.7 & 8.7 \\
\hline P-W-D & NT & 308 & 2112 & 563 & 659 & 731 & 4373 & 39287 & 2897 & 551 & 551 & 9.1 & 9.8 \\
\hline D-C-P & NT & 308 & 2320 & 552 & 664 & 475 & 4319 & 37611 & 709 & 468 & 468 & 8.8 & 9.0 \\
\hline D-cP-P & NT & 308 & 1290 & 1067 & 710 & 601 & 3976 & 31186 & 6466 & 466 & 466 & 7.9 & 9.5 \\
\hline$L S D$ & & - & 485 & & & & 485 & 3954 & & 97 & 74 & 1.7 & 1.4 \\
\hline
\end{tabular}

a Abbreviations for rotation, tillage are same as in Table 2.

output of durum wheat was lower when grown after durum wheat than after pulses.

Energy output/input ratio (O/I) of treatments under high $\mathrm{N}$ level were lower than those under low and medium $\mathrm{N}$ levels irrespective of crop stubbles (Fig. 3). Maximum O/I was obtained by the medium N level treatment for durum wheat grown on durum wheat stubble, while $\mathrm{O} / \mathrm{I}$ was maximized at low $\mathrm{N}$ level treatments for durum wheat grown on mustard and pulse crops. Higher O/I for durum wheat grown on pulse stubbles than for durum wheat grown on durum wheat stubble indicated that previous pulse crops promote energy use efficiency of durum wheat production.

\section{Discussion}

\subsection{Comparison with other studies}

The grain transformities of different rotations ranged from $0.68 \mathrm{E}+05$ sej $\mathrm{J}^{-1}$ for P-W-D to $1.21 \mathrm{E}+05$ sej $\mathrm{J}^{-1}$ for F-D-D MT (Table 3), similar to values of $0.89 \mathrm{E}+05$ sej $\mathrm{J}^{-1}$ for lupine-durum wheat rotation in Australia (Lefroy and Rydberg, 2003) and $1.21 \mathrm{E}+05 \mathrm{sej} \mathrm{J}^{-1}$ for durum wheat production in Italy (Ulgiati et al., 1994). But transformities in our rotation systems were higher than that of $0.65 \mathrm{E}+05 \mathrm{sej} \mathrm{J}^{-1}$ for continuous durum wheat production in Denmark (Ghaley and Porter, 2013) and 0.22-0.35 E+05 sej J ${ }^{-1}$ for maize production in Argentina (Rótolo et al., 2015). Our lower grain production efficiency was attributed to much lower grain yield in the semiarid Canadian prairie. Energy use efficiency, expressed as energy output/energy input ratio $(\mathrm{O} / \mathrm{I})$, for our different systems (Table 5) was comparable to those of Zentner et al. (2011) of 369-528 $\mathrm{g} \mathrm{MJ}^{-1}(\mathrm{G} / \mathrm{I})$ and 6.84-9.20 (O/I) for various systems in Dark Brown Chernozemic soils of Saskatchewan but lower than those in the more humid Black Chernozemic soils of Manitoba, where yields tend to be higher [698-860 $\mathrm{g} \mathrm{MJ}^{-1}$ (G/I) and 10.32-14.81 (O/I)] (Khakbazan et al., 2009).

\subsection{Benefits from crop diversification, pulse crops, and $N$ fertilizer}

Significantly lower grain transformity (Table 3) and higher energy use efficiency (Table 5) for rotations with pulses demonstrated their benefit towards higher efficiency in crop production. Furthermore, grain transformity of durum wheat grown on durum wheat stubble were $28-40 \%$ higher than durum wheat grown on canola or pea stubbles in rotation systems of systems experiment (Fig. 2), while grain transformity of durum wheat grown on durum wheat stubble were $19-100 \%$ and $15-57 \%$ higher than that of durum wheat grown on mustard and pulses stubbles under different $\mathrm{N}$ fertilizer levels of the stubble experiment (Fig. 3). O/I values for durum wheat grown on durum wheat stubble were $6-14 \%$ and $2-19 \%$ lower than those for durum wheat grown on mustard and pulse crop stubbles of stubble experiment (Fig. 3). These results indicate a significantly higher durum wheat production efficiency grown on oilseed or pulse crop stubbles.

The benefits of crop diversification are mainly derived from pulse crops in the system. It has been widely demonstrated that pulse crops had enormous benefits to durum wheat-based dryland cropping systems in the northern Great Plains (Angadi et al., 2008; Cutforth et al., 2009; Gan et al., 2015; Miller et al., 2002). Pea and lentil use less water than cereals, chickpea, canola, or mustard (Angadi et al., 2008), leaving more soil water for subsequent crops, particularly below $60 \mathrm{~cm}$ depth, thereby increasing water use efficiency of the entire rotation (Gan et al., 2009). The similar benefit of durum wheat following chickpea to pea and lentil indicates that water conservation benefit of pea and lentil was not large in our study. A key benefit of pulses is that they fix atmospheric $\mathrm{N}_{2}$ by root nodule symbiosis and the slow-release of $\mathrm{N}$ from pulse residues and roots favors the growth of succeeding crop (Boddey et al., 2010). In the systems experiment only rotations with pulses had more $\mathrm{N}$ removed in grain than added in fertilizer (Table 1 ) thereby confirming that this benefit as pulses in rotations fundamentally changed the $\mathrm{N}$ regime. Pulses can also have non- $\mathrm{N}$ benefits such as promoting larger microbial populations in the rhizosphere (Chen et al., 2008). Results from the stubble experiment indicated a benefit of pulses across $\mathrm{N}$ fertilizer levels, which suggest that biological function benefits to subsequent durum wheat were important. Although the high fertilizer $\mathrm{N}$ rates was more inefficient based on emergy and energy than low or moderate rates (Fig. 3), the high rate of $\mathrm{N}$ fertilizer did confer yield and grain protein benefits (Fig. 1). Protein is highly valued in durum wheat so its price increases with protein content (Olmos et al., 2003). Considering that $\mathrm{N}$ fertilizer is relatively inexpensive compared to the value of high-protein durum wheat, the economic pressure will be to use high fertilizer additions despite the energy or emergy inefficiencies.

\subsection{Effect of SOC change on sustainability of cropping systems}

In the systems experiment, SOC change was clearly related to fallow in the systems (Table 1). The continuous rotations had apparent increases in SOC, attributed to the rebuilding of SOC on these soils that were predominantly in two-year crop-fallow rotations throughout the 20th century (Campbell et al., 2002; Monreal and Janzen, 1993). In contrast, fallow favored net loss of SOC (Malhi et al., 2009; Zentner et al., 2011). The fallow favored yield through the buildup of soil moisture and mineralized nutrients (Branca et al., 2013). Using a C:N ratio of 9.9:1 for this soil (Campbell 

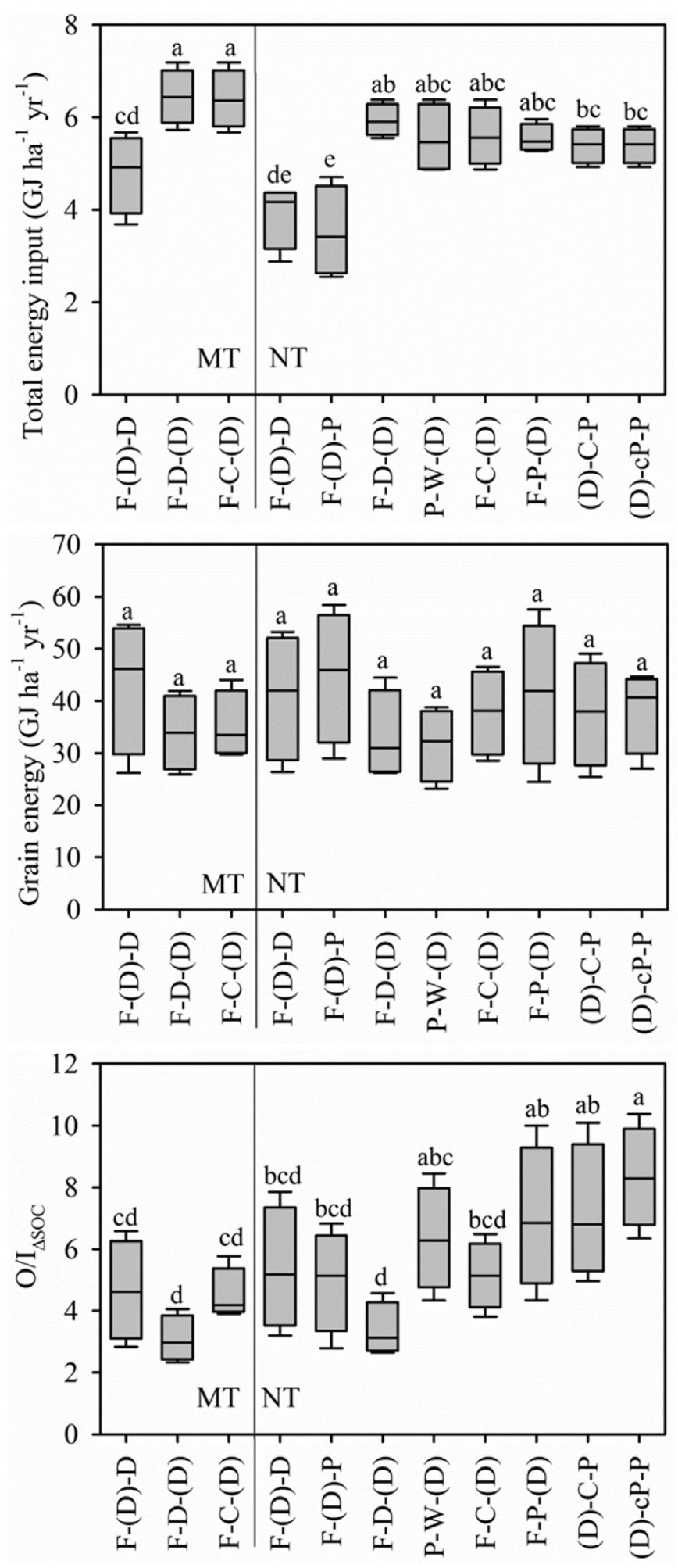

Fig. 4. Total energy input, grain energy, and $\mathrm{O} / \mathrm{I}_{\Delta \mathrm{Soc}}$ of durum wheat in different rotation systems from 2002 to 2005 . See Table 2 for abbreviations of rotation systems.

et al., 1998), the estimated soil N source for 1995 to 2005 from SOC decrease for rotations without pulses would range from about $4.0 \mathrm{~kg} \mathrm{~N} \mathrm{ha}^{-1} \mathrm{yr}^{-1}$ for F-C-D under MT to $12.7 \mathrm{~kg} \mathrm{~N} \mathrm{ha}^{-1} \mathrm{yr}^{-1}$ for F$\mathrm{D}$-D under MT. These mineralized nutrients from organic matter are non-renewable resources $N$ (i.e. SOC decrease) according to emergy analysis.
Whether or not changes in SOC are taken into account will profoundly affect the evaluation results (Lu et al., 2010; Rodrigues et al., 2003), as demonstrated also in our results. The ESI, widely used as an indicator for system sustainability in emergy analysis (Brown and Ulgiati, 1997), was the highest for rotation F-D-P in the present study (Table 3 ), which was primarily resulted from its lower $\mathrm{N}$ fertilizer application rate (Table 1 ). The $\mathrm{F}-\mathrm{D}-\mathrm{P}$ rotation system would be regarded as the most sustainable system for its high ESI if the SOC change was not considered. However, F-D-P rotation also showed the highest SOC decrease among all rotation systems during the study period (Table 1). Considering the importance of SOC in agricultural systems in maintaining soil fertility and quality, the F-D-P rotation, with its excessive SOC depletion, cannot be recommended as a sustainable rotation system. A modified emergy sustainability index considering the change of storage $\left(\mathrm{ESI}_{\Delta \mathrm{Q}}\right)$ was used in the present emergy analysis, which resulted in an almost completely opposite indication that continuous rotations (P-W-D, D-C-P, and D-cP-P) were more sustainable than fallow including systems in the Canadian prairie because of their higher $\mathrm{ESI}_{\Delta \mathrm{Q}}$ values (Table 3). Although continuous rotations needed more fertilizer $\mathrm{N}$ inputs, they obtained more grain yield and most importantly resulted in a significant increase in SOC (Table 1). Assuming the $\mathrm{C}: \mathrm{N}$ ratio of $9.9: 1$ is maintained, there would be an indicated $\mathrm{N}$ sink in soil organic matter varying from $1.6 \mathrm{~kg} \mathrm{~N} \mathrm{ha}^{-1} \mathrm{yr}^{-1}$ for D-O-p to $18.4 \mathrm{~kg} \mathrm{~N} \mathrm{ha}^{-1} \mathrm{yr}^{-1}$ for D-O/p-p. These results suggested the importance of including SOC in sustainability evaluation of agricultural systems. The method employed in the present emergy analysis will double the emergy yield $(Y)$ of some rotation systems by taking the increase of SOC as a co-product with grain output, but it provided the ability of using $\mathrm{ESI}_{\Delta \mathrm{Q}}$ in emergy analysis for system sustainability evaluation by considering the SOC changes. Although this approach is not yet fully accepted in emergy analysis, we believe the ability to fully account for SOC changes is worthwhile and in agreement, the same approach has been used in some other studies (Lu et al., 2009, 2010).

Energy analysis has been widely used for evaluating the energy use efficiency and sustainability of agricultural systems. However, environmental contributions, which are also critical to food production both directly and indirectly, are not included in most of the current energy analysis (e.g., Hoeppner et al., 2007; Khakbazan et al., 2009; Zentner et al., 2011). In the present energy analysis, energy use efficiency index, $\mathrm{O} / \mathrm{I}$, was the highest for F-D-P rotation when SOC changes were not taken into account, but the modified index, $\mathrm{O} / \mathrm{I}_{\Delta \mathrm{SOC}}$, were higher for continuous rotations than fallow including rotations (Table 5). The modified energy use efficiency, $\mathrm{O} /$ $\mathrm{I}_{\Delta \mathrm{SOC}}$ in the present energy analysis, regarded $\Delta \mathrm{SOC}$ as energy input where the system depleted SOC, but regarded $\triangle S O C$ as energy output where the system accumulated SOC. This approach successfully took SOC change into account in energy analysis and clearly showed higher energy use efficiency for rotation systems with SOC increase (Table 5). Although no allowance was made for the removal of energy captured in terms of SOC increases or losses (Zentner et al., 2011), more energy captured by SOC increase would further stimulate photosynthesis through enhanced plant growth (Govers et al., 2013) and benefit the crop production and system sustainability since up to $90 \%$ of the solar energy invested in carbon by plants on land ends up in the soil (Gessner et al., 2010). The importance of soil as a mediator of solar energy, encompassing soil in system analysis, has been emphasized in a broader ecological view (Janzen, 2015). Therefore, the use of $\mathrm{O} / \mathrm{I}_{\Delta \mathrm{SOC}}$ by including SOC change is highly warranted in energy analysis.

When the effect of SOC change was taken into consideration in the indices, the better sustainability was indicated through higher $\mathrm{ESI}_{\Delta \mathrm{Q}}$ and EBR (Table 3) and improved energy use efficiency 
through higher $\mathrm{G} / \mathrm{I}_{\Delta \mathrm{SOC}}$ and $\mathrm{O} / \mathrm{I}_{\Delta \mathrm{SOC}}$ (Table 5 ).

\subsection{Comparative usefulness of emergy or energy indicators}

The emergy and energy indicators were responsive to factors of cropping sequence, tillage intensity, and $\mathrm{N}$ fertility. The sustainability benefit of the continuous rotations over rotations with fallow was not obvious for several indices such as ESI or O/I (Tables 3 and 5). However, the indices involving the effects of $\triangle \mathrm{SOC}$, $\mathrm{ESI}_{\Delta \mathrm{Q}}$ and $\mathrm{O} / \mathrm{I}_{\Delta \mathrm{SOC}}$, were most able to identify sustainability and efficiency benefits of continuous rotations.

In the present study, the natural emergy inputs $(R)$ were the same for all cropping treatments since they were conducted in one location. Thus, this study does not demonstrate the capability of the emergy analysis to compare relative performance of systems across different locations having different natural emergy inputs (Amaral et al., 2016; Kharrazi et al., 2014).

Within the systems experiment, the F-D-P rotation was the most troubling to fairly evaluate using the emergy and energy-based sustainability and efficiency indicators. Since this rotation had the greatest SOC loss (Table 1), it is not sustainable over the long term (Tilman et al., 2002). However, several indicators that did not include $\triangle S O C$ indicated that this rotation was superior to any other, notably EYR, ESI, G/I, and O/I (Table 3). In contrast, the indicators that included the effect of $\Delta S O C, E_{\Delta Q}, G / I_{\Delta S O C}$, and $\mathrm{O} / \mathrm{I}_{\Delta S O C}$, downgrade the relative performance of the F-D-P rotation (Tables 3 and 5). Hence including $\triangle S O C$ within emergy and energy sustainability indices provides more correct assessments of sustainability.

The energy use efficiency indicators of $\mathrm{G} / \mathrm{I}_{\Delta S O C}$ and $\mathrm{O} / \mathrm{I}_{\Delta \mathrm{SOC}}$ were most effective in identifying the relatively poor performance of this system once effects of non-renewable SOC loss were included. In comparison, $\mathrm{ESI}_{\Delta \mathrm{Q}}$ did not effectively indicate that this rotation was not as sustainable as other rotations. The $\mathrm{O} / \mathrm{I}_{\Delta \text { SOC }}$ indicator was also more effective than the emergy indicators to demonstrate the benefits of the more diversified F-C-D rotation over the monoculture F-D-D rotation (Table 5). However, the energy-based indicators of $\mathrm{G} / \mathrm{I}_{\Delta S O C}$ and $\mathrm{O} / \mathrm{I}_{\Delta S O C}$ did not indicate the inherent resource inefficiency of fallow in the F-P-D compared to that of continuous rotations. The emergy indicator, $\mathrm{ESI}_{\Delta \mathrm{Q}}$, did capture the inherent resource disadvantage of F-P-D. Consequently, there are advantages to using both emergy and energy analyses indicators together to have a more informative and integrative assessment of relative sustainability and efficiency of cropping systems.

\section{Conclusions}

This study carried out an integrated emergy and energy analysis of different cropping rotation systems and $\mathrm{N}$ fertilizer and stubble treatments on an Orthic Brown Chernozem soil at Swift Current, Saskatchewan, Canada to assess the sustainability of varied cropping systems in the Canadian prairie. Pulse-including rotations showed higher energy use efficiency and production efficiency (lower transformity) among fallow including systems, mainly due to multiple beneficial effects of pulse crops on the succeeding crop in the rotation. Furthermore, durum wheat grown on pulse stubbles showed notably higher production efficiency and energy use efficiency than durum wheat grown on durum wheat stubbles from both systems experiment and stubble experiment, which further confirmed the effect of pulse crops on the production efficiency of the succeeding crops.

A modified emergy sustainability index $\left(\mathrm{ESI}_{\Delta \mathrm{Q}}\right)$ was used in the present emergy analysis and a modified energy use efficiency $(\mathrm{O} /$ $\mathrm{I}_{\Delta \mathrm{SOC}}$ ) was introduced in the present energy analysis by considering the change of SOC in the systems. By using these indicators in our study, both emergy and energy analysis showed that continuous rotation systems were the best production systems for attaining higher production efficiency and sustainability in the Canadian prairie. Although continuous rotations relied on more $F_{N}$ (mainly $\mathrm{N}$ fertilizer) resulting in higher ELR, they had higher grain yield, increased SOC, and consequently higher crop production efficiency (lower transformity), higher energy use efficiency $\left(\mathrm{G} / \mathrm{I}_{\Delta \text { SOC }}\right.$ and $\mathrm{O} /$ $\mathrm{I}_{\Delta \mathrm{SOC}}$ ), and higher system sustainability $\left(\mathrm{ESI}_{\Delta \mathrm{Q}}\right)$ when compared to fallow-including rotations. In contrast, fallow-including rotations, especially F-D-P rotation, required lower $F_{N}$ but consumed much higher SOC, which led to much lower sustainability. These results indicated that the sustainability of agricultural systems relied more on SOC change. Therefore, $\mathrm{ESI}_{\Delta \mathrm{Q}}$ and $\mathrm{O} / \mathrm{I}_{\Delta \mathrm{SOC}}$ are recommended as sustainability indicators in emergy and energy analysis respectively, which provide useful tools for assessing sustainability of agricultural systems. However, these indicators could not capture comprehensive performance of system in isolation; they should be used together to provide a more informative assessment of relative sustainability and efficiency of cropping systems.

\section{Acknowledgements}

This work was funded by Agriculture and Agri-Food Canada. The first author acknowledges the Natural Sciences and Engineering Research Council of Canada for the opportunity to work at AAFC as a postdoctoral fellow. Funding support for the systems experiment from Alberta Pulse Growers, Western Grains Research Foundation, and from AAFC is gratefully acknowledged. The stubble experiment was supported by the Canada-Saskatchewan Agri-Food Innovation Fund. The authors are indebted to the numerous technical staff and students who ably managed and collected data on the systems and stubble experiments.

\section{Appendix A. Supplementary data}

Supplementary data related to this article can be found at https://doi.org/10.1016/j.jclepro.2017.10.200.

\section{References}

Amaral, L.P., Martins, N., Gouveia, J.B., 2016. A review of emergy theory, its application and latest developments. Renew. Sust. Energy Rev. 54, 882-888.

Angadi, S.V., McConkey, B.G., Cutforth, H.W., Miller, P.R., Ulrich, D., Selles, F, Volkmar, K.M., Entz, M.H., Brandt, S.A., 2008. Adaptation of alternative pulse and oilseed crops to the semiarid Canadian Prairie: seed yield and water use efficiency. Can. J. Plant Sci. 88, 425-438.

Arcand, M.M., Lemke, R., Farrell, R.E., Knight, J.D., 2014. Nitrogen supply from belowground residues of lentil and wheat to a subsequent wheat crop. Biol Fert. Soils 50, 507-515.

Boddey, R.M., Jantalia, C.P., Conceiçao, P.C., Zanatta, JA, Bayer, C., Mielniczuk, J., Dieckow, J., Dos Santos, H.P., Denardin, J.E., Aita, C., Giacomini, S.J., Alves, B.J.R. Urquiaga, S., 2010. Carbon accumulation at depth in Ferralsols under zero-till subtropical agriculture. Glob. Change Biol. 16, 784-795.

Branca, G., Lipper, L., McCarthy, N., Jolejole, M.C., 2013. Food security, climate change, and sustainable land management. A review. Agron. Sustain. Dev. 33 635-650.

Brown, M.T., Campbell, D.E., De Vilbiss, C., Ulgiati, S., 2016. The geobiosphere emergy baseline: a synthesis. Ecol. Model 339, 92-95.

Brown, M.T., Ulgiati, S., 1997. Emergy-based indices and ratios to evaluate sustainability: monitoring economies and technology toward environmentally sound innovation. Ecol. Eng. 9, 51-69.

Brown, M.T., Ulgiati, S., 2004. Emergy analysis and environmental accounting. In: Cleveland, C.J. (Ed.), Encyclopedia of Energy. Elsevier, New York, pp. 329-354.

Campbell, C.A., Selles, F., Lafond, G.P., McConkey, B.G., Hahn, D., 1998. Effect of crop management on $\mathrm{C}$ and $\mathrm{N}$ in long-term crop rotations after adopting no-tillage management: comparison of soil sampling strategies. Can. J. Soil Sci. 78, 155-162.

Campbell, C.A., Zentner, R.P., Gameda, S., Blomert, B., Wall, D.D., 2002. Production of annual crops on the Canadian prairies: trends during 1976-1998. Can. J. Soil Sci. 82, 45-57.

Chen, M., Chen, B., Marschner, P., 2008. Plant growth and soil microbial community structure of legumes and grasses grown in monoculture or mixture. J. Environ. Sci. 20, 1231-1237.

Clarke, J.M., Clarke, F.R., Pozniak, C.J., 2010. Forty-six years of genetic improvement 
in Canadian durum wheat cultivars. Can. J. Plant Sci. 90, 791-801.

Cutforth, H.W., Angadi, S.V., McConkey, B.G., Entz, M.H., Ulrich, D., Volkmar, K.M. Miller, P.R., Brandt, S.A., 2009. Comparing plant water relations for wheat with alternative pulse and oilseed crops grown in the semiarid Canadian prairie. Can. J. Plant Sci. 89, 823-835.

Ferreyra, C., 2006. Emergy analysis of one century of agricultural production in the Rolling Pampas of Argentina. Int. J. Agric. Resour. Gov. Ecol. 5, 185-205.

Franzese, P.P., Rydberg, T., Russo, G.F., Ulgiati, S., 2009. Sustainable biomass production: a comparison between gross energy requirement and emergy synthesis methods. Ecol. Indic. 9, 959-970.

Gan, Y., Campbell, C.A., Liu, L., Basnyat, P., McDonald, C.L., 2009. Water use and distribution profile under pulse and oilseed crops in semiarid northern high latitude areas. Agr. Water Manage 96, 337-348.

Gan, Y., Hamel, C., O'Donovan, J.T., Cutforth, H., Zentner, R.P., Campbell, C.A., Niu, Y., Poppy, L., 2015. Diversifying crop rotations with pulses enhances system productivity. Sci. Rep. 5, 14625.

Gasparatos, A., 2011. Resource consumption in Japanese agriculture and its link to food security. Energy Policy 39, 1101-1112.

Gessner, M.O., Swan, C.M., Dang, C.K., McKie, B.G., Bardgett, R.D., Wall, D.H. Hättenschwiler, S., 2010. Diversity meets decomposition. Trends Ecol. Evol. 25 $372-380$.

Ghaley, B.B., Porter, J.R., 2013. Emergy synthesis of a combined food and energy production system compared to a conventional wheat (Triticum aestivum) production system. Ecol. Indic. 24, 534-542.

Govers, G., Merckx, R., Van Oost, K., van Wesemael, B., 2013. Soil organic carbon management for global benefits: a discussion paper. In: Workshop on Soil Organic Carbon Benefits: a Scoping Study, 10th-12th September 2012, Nairobi.

Hoang, V.-N., Alauddin, M., 2011. Analysis of agricultural sustainability: a review of exergy methodologies and their application in OECD countries. Int. J. Energy Res. 35, 459-476.

Hoeppner, J.W., Entz, M.H., McConkey, B.G., Zentner, R.P., Nagy, C.N., 2007. Energy use and efficiency in two Canadian organic and conventional crop production systems. Renew. Agr. Food Syst. 21, 60-67.

Janzen, H.H., 2015. Beyond carbon sequestration: soil as conduit of solar energy. Eur. J. Soil Sci. 66, 19-32.

Janzen, H.H., Beauchemin, K.A., Bruinsma, Y., Campbell, C.A., Desjardins, R.L. Ellert, B.H., Smith, E.G., 2003. The fate of nitrogen in agroecosystems: an illustration using Canadian estimates. Nutr. Cycl. Agroecosys 67, 85-102.

Khakbazan, M., Mohr, R.M., Derksen, D.A., Monreal, M.A., Grant, C.A., Zentner, R.P. Moulin, A.P., McLaren, D.L., Irvine, R.B., Nagy, C.N., 2009. Effects of alternative management practices on the economics, energy and GHG emissions of wheat-pea cropping system in the Canadian prairies. Soil Till. Res. 104, 30-38.

Kharrazi, A., Kraines, S., Hoang, L., Yarime, M., 2014. Advancing quantification methods of sustainability: a critical examination emergy, exergy, ecological footprint, and ecological information-based approaches. Ecol. Indic. 37, 81-89.

Lal, R., 2004. Soil carbon sequestration impacts on global climate change and food security. Science 304, 1623-1627.

Lefroy, E., Rydberg, T., 2003. Emergy evaluation of three cropping systems in southwestern Australia. Ecol. Model 161, 195-211.

Lu, H.-F., Kang, W.-L., Campbell, D.E., Ren, H., Tan, Y.-W., Feng, R.-X., Luo, J.-T., Chen, F.-P., 2009. Emergy and economic evaluations of four fruit production systems on reclaimed wetlands surrounding the Pearl River Estuary, China. Ecol. Eng. 35, 1743-1757.

Lu, H., Bai, Y., Ren, H., Campbell, D.E., 2010. Integrated emergy, energy and economic evaluation of rice and vegetable production systems in alluvial paddy fields: implications for agricultural policy in China. J. Environ. Manage 91, 2727-2735.

Ma, F., Eneji, A., Liu, J., 2015. Assessment of ecosystem services and dis-services of an agro-ecosystem based on extended emergy framework: a case study of Luancheng county, North China. Ecol. Eng. 82, 241-251.

Malhi, S.S., Brandt, S.A., Lemke, R., Moulin, A.P., Zentner, R.P., 2009. Effects of input level and crop diversity on soil nitrate-N, extractable $\mathrm{P}$, aggregation, organic $\mathrm{C}$ and N, and nutrient balance in the Canadian Prairie. Nutr. Cycl. Agroecosys 84
$1-22$.

McConkey, B.G., Liang, B.C., Campbell, C.A., Curtin, D., Moulin, A., Brandt, S.A., Lafond, G.P., 2003. Crop rotation and tillage impact on carbon sequestration in Canadian prairie soils. Soil Till. Res. 74, 81-90.

Miller, P.R., McConkey, B.G., Clayton, G.W., Brandt, S.A., Staricka, J.A., Johnston, A.M., Lafond, G.P., Schatz, B.G., Baltensperger, D.D., Neill, K.E., 2002. Pulse crop adaptation in the northern Great Plains. Agron. J. 94, 261-272.

Monreal, C.M., Janzen, H.H., 1993. Soil organic-carbon dynamics after 80 years of cropping a Dark Brown Chernozem. Can. J. Soil Sci. 73, 133-136.

Odum, H.T., 1988. Self-organization, transformity, and information. Science 242, $1132-1139$.

Odum, H.T., 1996. Environmental Accounting: Emergy and Environmental Decision Making. John Wiley \& Sons, New York.

Olmos, S., Distelfeld, A., Chicaiza, O., Schlatter, A.R., Fahima, T., Echenique, V., Dubcovsky, J., 2003. Precise mapping of a locus affecting grain protein content in durum wheat. Theor. Appl. Genet. 107, 1243-1251.

Park, Y.S., Egilmez, G., Kucukvar, M., 2016. Emergy and end-point impact assessment of agricultural and food production in the United States: a supply chain-linked Ecologically-based life cycle assessment. Ecol. Indic. 62, 117-137.

Pretty, J., 2008. Agricultural sustainability: concepts, principles and evidence. Philos. T. Roy. Soc. B 363, 447-465.

R Core Team, 2015. R: a Language and Environment for Statistical Computing. R Foundation for Statistical Computing, Vienna, Austria. https://www.R-project. org $/$.

Rodrigues, G.S., Kitamura, P.C., Sá, T.D.d.A., Vielhauer, K., 2003. Sustainability assessment of slash-and-burn and fire-free agriculture in Northeastern Pará, Brzail. In: Brown, MT (Ed), Emergy Synthesis 2: Theory and Application of the Emergy Methodology, the Center for Environmental Policy. Environmental Engineering Science. University of Florida, Gainesville, Florida, USA.

Rótolo, G.C., Francis, C., Craviotto, R.M., Ulgiati, S., 2015. Environmental assessment of maize production alternatives: traditional, intensive and GMO-based cropping patterns. Ecol. Indic. 57, 48-60.

Rydberg, T., Haden, A.C., 2006. Emergy evaluations of Denmark and Danish agriculture: assessing the influence of changing resource availability on the organization of agriculture and society. Agr. Ecosyst. Environ. 117, 145-158.

Shrestha, B.M., McConkey, B.G., Smith, W.N., Desjardins, R.L., Campbell, C.A., Grant, B.B., Miller, P.R., 2013. Effects of crop rotation, crop type and tillage on soil organic carbon in a semiarid climate. Can. J. Soil Sci. 93, 137-146.

St Luce, M., Grant, C.A., Zebarth, B.J., Ziadi, N., O'Donovan, J.T., Blackshaw, R.E., Harker, K.N., Johnson, E.N., Gan, Y., Lafond, G.P., May, W.E., Khakbazan, M., Smith, E.G., 2015. Legumes can reduce economic optimum nitrogen rates and increase yields in a wheat-canola cropping sequence in western Canada. Field. Crop. Res. 179, 12-25.

Tilman, D., Cassman, K.G., Matson, P.A., Naylor, R., Polasky, S., 2002. Agricultural sustainability and intensive production practices. Nature 418, 671-677.

Ulgiati, S., Odum, H.T., Bastianoni, S., 1994. Emergy use, environmental loading and sustainability an emergy analysis of Italy. Ecol. Model 73, 215-268.

Zentner, R.P. Basnyat, P. Brandt, S.A. Thomas, A.G., Ulrich, D. Campbell, C.A., Nagy, C.N., Frick, B., Lemke, R., Malhi, S.S., Fernandez, M.R., 2011. Effects of input management and crop diversity on non-renewable energy use efficiency of cropping systems in the Canadian Prairie. Eur. J. Agron. 34, 113-123.

Zhai, X., Huang D., Tang S. Li, S., Guo, J., Yang Y, Liu, H., Li, J., Wang, K., 2017. The emergy of metabolism in different ecosystems under the same environmental conditions in the agro-pastoral ecotone of northern China. Ecol. Indic. 74, 198-204.

Zhang, L.X., Yang, Z.F., Chen, G.Q., 2007. Emergy analysis of cropping-grazing system in Inner Mongolia Autonomous Region, China. Energy Policy 35, 3843-3855.

Zhang, X.H., Zhang, R., Wu, J., Zhang, Y.Z., Lin, L.L., Deng, S.H., Li, L., Yang, G., Yu, X.Y., Qi, H., Peng, H., 2016. An emergy evaluation of the sustainability of Chinese crop production system during 2000-2010. Ecol. Indic. 60, 622-633. 